\title{
The importance of knowledge transfer on the energy market
}

ABSTRACT: The Energy Law of April 10, 1997 initiated changes in the energy market in Poland. Actions taken on the basis of this law were aimed at the modernization and development of the power sector. Organizational and legal changes causing the development of distributed generation, thus increasing the level of market competition have been introduced. The care for high quality of customer service, including the protection of vulnerable customers, environmental protection, growing share of renewable energy and emission reduction requirements have become a reality. It seems, therefore, that it is necessary for the Polish energy sector to undergo permanent modernization, to develop the production and industrial infrastructure and to develop modern conventional technologies by way of implementing innovations in the field of energy companies. The author of the paper argues that it is indispensable to make a broadly understood transfer of knowledge and technology to the energy sector on the basis of a knowledge-based economy. This also applies to energy clusters, which currently constitute a platform for cooperation: entrepreneurs, scientific-research units, and public authorities. The functioning of these entities is an important catalyst for the transfer of knowledge and technologies. Their regional nature boosts competitiveness of the involved enterprises, and is a natural way of transferring knowledge to the energy market.

KEYWORDS: market liberalization, knowledge transfer to the energy market, electromobility, energy cluster

\footnotetext{
${ }^{1}$ Silesian University of Technology, The Organisation and Management Department; e-mail: radoslaw.miskiewicz@ polsl.pl
} 


\section{The modern knowledge based economy (KBE)}

The knowledge-based economy shapes a new stage of economic development of countries. Various definitions thereof are to be found in the source literature. It is often described as a knowledge-driven economy, where the emphasis falls on shaping its new structures under the influence of civilization and technological changes. Many terminological references, according to which it is a "benefits" economy, in which the majority of employees are employed in the services sector; economy of excess or rather "excessiveness"; based on knowledge management: generation, distribution, and application of knowledge and information (OECD); an economy in which there operate many enterprises basing their knowledge on their competitive advantage (Kukliński 2001) are used. The process also involves the reconstruction of intellectual and social capital, which P. Druker calls a pro-capitalist society, and D. Bell a postindustrial society, while A. Toffler terms this a third wave society. J. Naisbitt suggests that we are dealing with a knowledge society. What these considerations picture is the information society, information economy, networked economy, or third wave economy. The question arises how to form a modern knowledge-based economy and whether it is possible to control such a process. In the management sciences, the approach to building a knowledge-based economy boils down to creating conditions conducive to the creation and functioning of enterprises which base their competitive advantage on knowledge. Thus, this economy is shaped by such entities as: the state, local and regional authorities, enterprises as well as intellectual and academic environments (Nowak 2013).

At the basis of the concept of this "new economy" lies the observation, which shows that traditional factors of economic development, such as: land, natural resources, labor, or capital, maintain their fundamental meaning, but in the economic transformation of countries and regions it is the knowledge that becomes increasingly visible. Its importance is systematically growing, so that presently it is the most important factor of production and the main source of wealth. Experts suggest that knowledge is more than yet another critical factor of production. It is a source of renewal and a binding agent which combines and coordinates other factors of production. Thus, a new direction of development of the modern economy was created by the technological revolution of the second half of the twentieth century associated with the dynamic development of consumer electronics, the emergence of computers, new Information and Communication Technologies, as well as the emergence of a worldwide Internet network (Kukuła 2013).

The knowledge-based economy (KBE), as noted by P.M. Romer, is based primarily on information and knowledge, and emphasizes the attributes of the human mind, which are partially overt (explicit knowledge) and partly covert (hidden knowledge). The basis of modern management is the creation and use of new ideas in the techniques of processes which produce new products or services. The source of success lies therefore not in the allocation of rare resources, but in the creation of new knowledge which supplies ideas whose implementation increases the value of management effects. There is no single definition of KBE which everyone would found to be satisfying. According to experts from the Organization for Economic Co-operation 
and Development (OECD), a knowledge-based economy is the one which is directly based on the production, distribution, and application of knowledge and information. Only in 2001 representatives of the Ministry of Economy of the Republic of Poland suggested that the KBE is an economy, in which knowledge is the main factor of productivity and economic growth before work, capital, raw materials, and energy. An interesting attempt to define the KBE would be the proposal of R. Żelazny, according to whom the KBE is an economy based on increasing share of knowledge and information in achieving the economic objective, which is reflected in the development of knowledge-based technologies (in particular the ICT) and their expansion into all areas of management (e-Poland 2001).

From a practical point of view, as J. Kleer (2009) suggests, a knowledge-based economy is one that: achieves a high level of development, which currently oscillates around USD 20,000 per citizen, and where the GDP structure is characterized by a $70 \%$ share of services in its formation; achieves a high level of education, where secondary education is considered as ubiquitous, and where at least a half of the professionally active population holds a degree; has a broad innovation base, and the share of expenditure on R\&D is around 3\% of GDP; is open to innovation, which is a function of at least three variables: creativity of people, demand for innovation, and an appropriate pro-innovative climate, which the state should form. It shapes the new economic and social structure as well as exerts significant modifications in the functions of the public sector. It is also worth emphasizing that two new, important categories appear - knowledge workers and knowledge-based companies. This has also been emphasized by P. Deuker who claims a knowledge worker is a person who uses his or her reason more than manual skills and is aware of how to allocate knowledge for purposes of productive use thereof.

Today, the new economy is based on five main carriers: science, high-tech industry, information society services, knowledge-intensive services, and education. The primary goal of its activity is to become acquainted with and define mechanisms of impact on the transformation and development of countries and enterprises. Therefore, modern management of economic processes and skillful management of people at all levels is indispensable. It exerts efficiency and stimulates innovation and development. However, it requires knowledge of a closer and further environment, the need to acquire and use knowledge, the need to transform the industrial society into information society, making the organization's ability to survive conditional on access to information and its competent processing, and adaptation to change. This implies also the need for taking a global view on the economy, market, environmental protection, and energy security, as well as to recognize the growing role of intangible assets, i.e. knowledge, intellectual capital, and information (Skrzypek 2011; Kleer 2009).

Theoretical foundations and economic practice shape contemporary new determinants. They prefer the process of shifting from a goods-oriented economy to a service-oriented economy; an increase in the number and impact of the class of professional and technical employees while the information society is organized around knowledge and information. Scientific research and development, the combination of science and technology as well as economics are the key to the information society, where the development of intellectual technology methods takes place. Its pillars are: ICT - Information and Communication Technology, human capital, social capital 
(trust, cooperation, and social networks), knowledge management at the organizational level, across all sectors, including the energy sector (Papińska-Kacperek 2006).

The Lisbon Strategy was an important institutional and legal basis for the functioning of $\mathrm{KBE}$ in the EU and Poland. Based on four main pillars, the Lisbon Strategy assumed extension of its institutional and legal environment (elimination of market barriers, stimulation of entrepreneurship); development of IT systems, creating financial, legal, and administrative opportunities favorable to innovation; dynamic development of information infrastructure and general education and training - investments in human capital, including lifelong learning, which was mentioned as the fifth pillar thereof. Unfortunately, as emphasized by M. G. Woźniak, the reasons of failure of the Strategy include, among others, weakness of political leadership and lack of social acceptance for increasing the role of the market, individual responsibility, and limiting the protective role of the state; too many objectives and priorities and, at the same time, low responsibility of individual Community states, which has led not only to the dilution of objectives, but also their mutual exclusion; contradictions between the interests of affluent and poorer Member States; often a faulty choice of regulators for harmonization of economic growth based on the expansion of the ICT sector and the diffusion of new technologies into traditional sectors with social cohesion, and others (Woźniak 2008).

New assumptions for the development of the knowledge-based economy have been included in the EU 2020 Development Strategy. The overarching assumptions thereof are: increasing the employment rate for people aged 20-64 from the current level of $69 \%$ to at least $75 \%$; increasing the volume of investments in research and development to $3 \%$ of GDP (with a particular emphasis on the private sector and new research tools); reducing greenhouse gas emissions by at least $20 \%$ compared to the 1990 level or by $30 \%$ should conditions prove favorable, increasing the share of renewable energy to $20 \%$ and achieving a $20 \%$ increase in energy efficiency; reduction to $10 \%$ of the share of persons with primary education from the current level of $15 \%$ while increasing the percentage of persons with higher education in the 30-34 age group to $40 \%$; a $25 \%$ reduction in the number of Europeans living below the poverty line in individual countries. These activities should result in a significant improvement in the economic situation of 20 million people (Gasz 2013).

On the basis of the above assumptions and the conviction that the state is able to render support to a knowledge-based economy through the proper macroeconomic policy, the rationalization of expenditure on research and development, appropriate education policy and reform of the education system with a view to improving the quality of education and better adjustment of the system to the requirements of the labor market developed in 2011 were the so-called indicators of the EU innovation table. The indicators fall into three main categories:

$\checkmark$ enables, i.e. basic elements enabling the emergence of innovations (human resources, financial resources and support, open and attractive research and scientific systems);

$\downarrow$ business activities - showing the degree of innovativeness of European businesses (investments, networking and entrepreneurship, intellectual assets);

$\downarrow$ outputs - illustrating how innovation translates into benefits for the economy (innovators, economic effects). 
The indicators form part of the National Reform Programs of the Member States for the implementation of the Europe 2020 Strategy, the aim of which is to build sustainable foundations for economic growth, thus combining EU objectives with national priorities. Table No. 1 presents indicators for growth-oriented reforms aimed at achieving smart and sustainable growth supporting social inclusion.

TABLE 1. EU-wide and national objectives under the Europe 2020 strategy

TABELA 1. Cele ogólnounijne i krajowe w ramach strategii Europa 2020

\begin{tabular}{|c|c|c|}
\hline Objectives & $\begin{array}{l}\text { Objective fulfillment } \\
\text { rate for the entire EU }\end{array}$ & $\begin{array}{l}\text { Objective fulfillment } \\
\text { rate for Poland }\end{array}$ \\
\hline Increase in employment & $\min .75 \%$ & $\min .71 \%$ \\
\hline Increase in spending on research and development & $\min .3 \%$ GDP & $\min .1 .7 \%$ GDP \\
\hline Reduction of $\mathrm{CO}_{2}$ emission * (compared to the 1990 level) & $\min .-20 \%$ & $\max .14 \%$ \\
\hline $\begin{array}{l}\text { Increase in the share of renewable energy in the energy } \\
\text { balance }\end{array}$ & $\min .20 \%$ & $\min .15,48 \%$ \\
\hline $\begin{array}{l}\text { Improvement of energy efficiency - reduction of energy } \\
\text { consumption }\end{array}$ & $\min .20 \%$ & $\min .14 \%$ \\
\hline Limiting early school leaving & $\max .10 \%$ & $\max .4,5 \%$ \\
\hline Increase in the number of people with higher education & $\min .40 \%$ & $\min .45 \%$ \\
\hline $\begin{array}{l}\text { Reduction of the number of people at risk of poverty or social } \\
\text { exclusion (of the number of people) }\end{array}$ & $\min .20,000,000$ & $\min .1,500,000$ \\
\hline
\end{tabular}

Source: Nowak 2013.

Currently, the EU is implementing seven flagship initiatives: - Innovation Union - improving the framework conditions for innovation and using innovation to solve most important social and economic problems identified in the Europe 2020 strategy; - Youth on the move - improving quality at all levels of education and training and increasing the attractiveness of European higher education in the international arena; - A Digital Agenda for Europe - Achieving lasting economic and social benefits from a digital single market based on broadband Internet access; - A resource-efficient Europe - supporting change towards a low-carbon economy and more efficiently benefiting from environmental resources, and striving to eliminate the dependence of economic growth on degradation of the natural environment; - Industrial policy for the globalization era - improving conditions for entrepreneurship, especially SMEs (Small and Medium Enterprises), and supporting the development of a strong industrial base, capable of competing on a global scale; - An agenda for new skills and employment - creating conditions for modernizing labor markets by facilitating mobility of workers and improving their skills in order to increase employment levels and ensure sustainability of European social models; - European anti-poverty program - ensuring economic, social, and territorial cohesion by helping poor and excluded persons and enabling them to actively participate in economic and social life. The activities included in programme apply also to the power sector and processes shaping the power market. 


\section{Knowledge and innovation transfer}

Violation of balance in the contemporary global world manifests itself in disrupting the socio -economic order. This results in the syndrome of increasing impermanence in the economy and internal structures thereof. It also has an adverse effect on the economic and political transformation of countries, crisis, high-levelled poles of wealth and poverty, stability of labor markets, unemployment, social dysfunction, demographic and ecological processes. According to L.C. Thurow, this violation of equilibrium is caused by movement of the so-called five economic plates, important from the point of view of global transformations (Mączyńska 2014). The assertion that modern markets and economies are the most complex economic systems that science knows becomes highly relevant (Colander et al. 2010; and also Jakimowicz 2016). In the global economy these phenomena exert a significant impact on the financial standing of enterprises, conditions of their environment, and trigger the need to look for new directions of development (Podczarski 2016). Building a market economy on the basis of its new paradigm (knowledge, capital, land, production, and globalization), in which knowledge and innovation play a key role, have become a challenge for countries and enterprises striving for a high level of development and competitiveness. This new economy, or the digital or network economy, is gaining more and more recognition among economists and practitioners of economic life (Toffler 2003; Jakimowacz 2016).

The knowledge and information based economy creates new solutions which relate directly to production and distribution, while high technology industries are seen as carriers of knowledge. New technologies and products, supported by highly qualified labor resources, determine the innovativeness of a given economy, and thus modernity and dynamics thereof (Porter 1992; Karczewski and Marcisz 2013). Key (technological and coordinating), auxiliary and market knowledge becomes desirable, or even strategic. It exerts a fundamental impact on the achievement of the objectives of the company and its competitiveness. It is also worth noting that with a view to the degree of generality of knowledge exploited in the enterprise, such knowledge may be divided into theoretical, empirical, and controlling processes of using the previous two types thereof (Flaszewska 2016; Skrzypek 2010). A. Polak and R. Miśkiewicz also believe that such fields of knowledge as: system and environment, threats, resources, technical preparation, processes, undertakings within the field of procurement, logistics, planning, finance, indications for use and expressive content significantly affect the functioning of an innovative enterprise (Polak 2012; Miśkiewicz 2017).

In the field of knowledge, the elements hidden under the notion of suppliers and co-operators play an important role. It seems interesting that knowledge is not only understood as familiarity with most favorable sources of supply and markets, but above all, the relations established by people employed in organizational cells dealing therewith. Their personal connections with counterparts in procurement and disposal are valuable knowledge, useful in relations with the environment. But taking over the company along with such knowledge is very difficult since this 
is typical tacit knowledge, carried by individual employees. The knowledge about competition, expressed in the obtained information and carried out analyzes, though also from employees being sources of information specialized in this field, and having access to such knowledge on the basis of private connections is also valuable. This last type of knowledge is nowhere to be recorded and is typical tacit knowledge. Within the field of threat, quality is the key priority. It may be understood in two ways - as a threat of being overtaken by competitors in terms of quality or as a decrease in the quality of own products. In the first case we are dealing with a similar situation as in the case of knowledge about competitors. Therefore, it is worth having knowledge about the quality level at the competitors or research processes and innovations carried out by the competitor, obtained certificates and awards, etc. This knowledge, while being covert, signals threats to the management of the company. In the latter case, the knowledge of quality is explicit knowledge, which does not diminish the value thereof. Such knowledge is important in order to prevent losses resulting from shortages and complaints as well as for purposes of visibility of the company on the market (Davenport 2007). These considerations show that organizational knowledge creates a useful methodological and practical basis. One should therefore accept the assertion that successful organizations are exclusively those which consistently and consciously acquire new knowledge, disseminate it across the entire organization, and quickly transform themselves into intelligent organizations (Kang et al. 2010; Dźwigoł 2010).

At present, knowledge is recognized as the most important economic asset. It has special features with regard to: indeterminacy of applications, effects, carrier, risk of use, and outlays. A. Toffler emphasizes its other values pointing to: dominance, inexhaustibility, simultaneity, and non-linearity (Strojny 2000). On the other hand, J. Klug, W. Stein and T. Licht list the following to be the key characteristics of knowledge: subjectivity, transferability, embedding, self-supply, impermanence, and spontaneity (Kang et al. 2010).

It is worth emphasizing that tacit knowledge means the experience, skills, and relationships often expressed through the determination of know-how. On the other hand, explicit knowledge is defined as articulated knowledge, and often to a large extent overt. These terminological references and classifications of knowledge in the part of the source literature result in generating knowledge models applicable in the market economy and enterprises. Hence the Japanese, resource, or process models. The latter is of great practical importance. It was built on the basis of experience of functioning of large US and British companies. Knowledge management was treated as a whole of processes enabling the creation, dissemination, and use of knowledge in order to achieve objectives of the organization. Considerations of T.H. Davenport and L. Prusak overlap with the above as they point to the occurrence of successive processes in knowledge management, i.e.: the creation of knowledge, rendering the knowledge overt, and knowledge transfer (Davenport and Prusak 1998; April and Majewski 2001; Skyrme 1999). Therefore, in the Polish circumstances knowledge management includes: company strategy, entrepreneurship, management of people, processes and quality, marketing, accounting and finance, IT systems and IT development for purposes of management. This means that the knowledge transfer is internal and related to the environment of the company (Klincewicz 2008; Flaszewska 2016). 
A slightly different attitude may be found in J. Kang, M. Rhee, and K.H. Kang, who also define the transfer through its functions, but include the creation of knowledge. Hence, knowledge and transfer thereof would overlap in terms of the concept (Kang et al. 2010). A. Ring and $\mathrm{H}$. Öfverström believe that the different terms of knowledge transfer used in the literature boil down to epistemological differences, i.e. to the use of different terminology (Ring and Öfverström 2000). A case in point would be that concepts such as the combination of knowledge, its merging and creation or "teaching" describe practically the same thing. They go on to argue that views on this matter, expressed, for example, by C. Bartlett and S. Ghoshal, I. Nonaka and H. Takeuchi, A. Hedlund, B. Kogut and U. Zander, present discrepancies only in writing because the transfer is looked into here at different angles (Bartlett and Ghoshala 2011). In connection with the above, one should assume that the above-mentioned scholars define the knowledge and its transfer as identical, the only difference being a different approach to the issue. While one may generally agree with such a view, it is subject to doubts whether acquiring knowledge for example by way of acquisitions or mergers, which is a typical case of knowledge transfer between companies today, corresponds to the actual state when it comes to the creation of knowledge. Such an approach may be relevant in the case in which the acquired knowledge is subject to expanding (combining) by way of merging it with another element. However, in certain cases, the purpose of acquiring knowledge is simply to obtain access to licenses, patents, innovations, etc., without immediate further improvement thereof. This is not the case of creating knowledge (Nonake and Takeuchi 1998; Hedlund 1994; Kogut and Zander 1993). Knowledge transfer is inextricably linked to technological innovations which were scientifically addressed in the 1960s. Initially, the large absorption of markets guaranteed to enterprises, even highly energy-intensive, significant profitability of production, which did not reduce its costs. At this time, the focus of engineers fell not on the quality and uniqueness of the manufactured product, but on maximizing the production capacity of the company. In the literature on economics and management sciences, the technology transfer concerns the process of adapting the results of scientific research, patents or original ideas to their practical application in production. The system of knowledge, techniques, qualifications of expert knowledge and organization applied in manufacturing, sale, and use of goods and services which meet economic and social demand in the global economy has become a civilization challenge (Szatkowski 2016; Santarek et al. 2008).

The participants of the technology transfer process are government organizations, regional institutions, technical universities, research centers, large and small companies, inventors and entrepreneurs. The process of technology transfer itself is conditioned by many factors including, among others, the study of technology development, purpose, the ability to adapt technological knowledge and flow channels thereof (Jasiński 2006; Rybiński 2015). 


\section{Transfer of knowledge to the energy market}

Electricity is currently an extremely peculiar commodity. On the one hand, it may be produced and sold, while on the other hand it is not possible to effectively store larger quantities thereof. The sanctioning of energy as a commodity, which is not only generally available, but also subject to marketing laws in Poland occurred in 1997 when the Energy Law came into force. However, the fact that, despite numerous technical, technological, and legislative revolutions which the global and Polish energy industry has been through, coal remains the basic raw material for electricity generation as illustrated in Figure 1, is still worrying. The new energy production methods are being developed at a rapid pace, and the already existing ones are being improved. In the wake of technological development, legislative bodies are trying to adapt the regulations to the real market. This is evidenced by continuous amendments to the law - the three-pack energy regulating the markets: RES (Renewable Energy Sources), energy, and gas and prosumer.

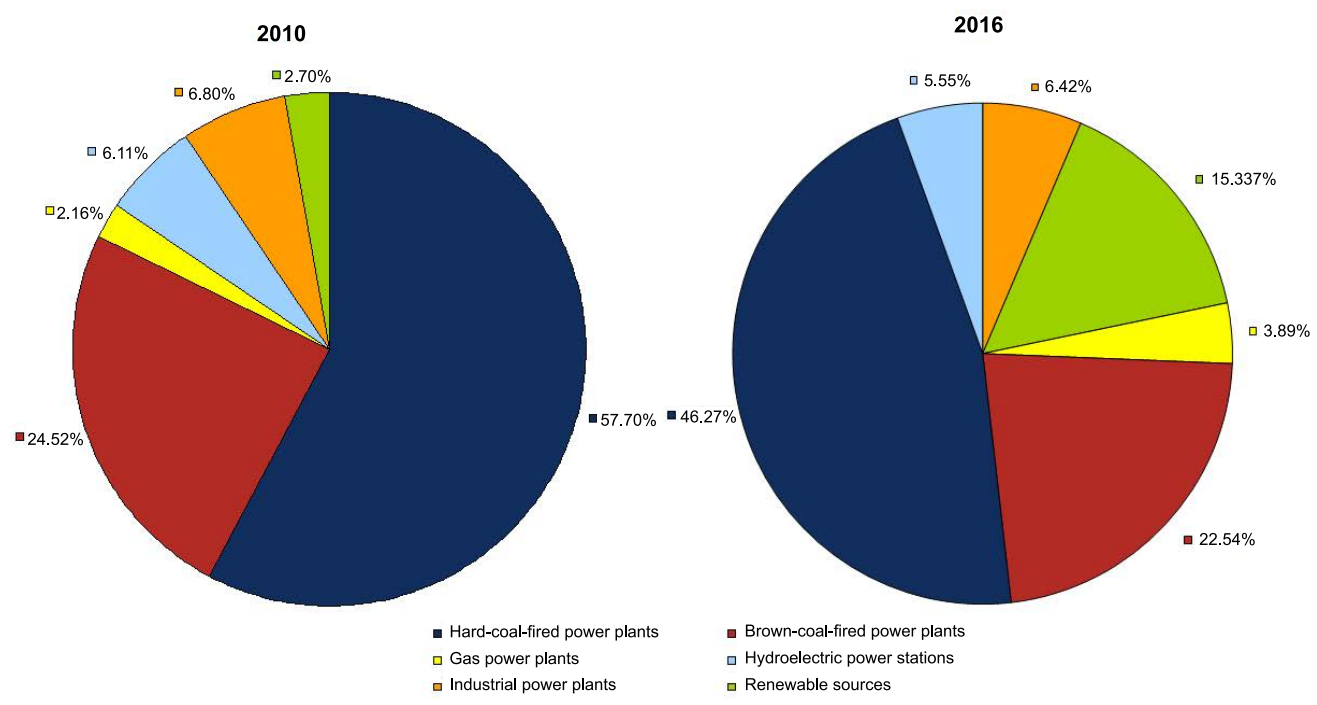

Fig. 1. Structure of electricity production in Poland by raw materials (2015) Source: Data by PSE (Polish Power System), The 2010 Report - 2016 KSE, www.pse.pl

Rys. 1. Struktura produkcji energii elektrycznej w Polsce wg surowców (2015)

Market trends may be looked into from several angles. Producers obviously stand at the beginning of the chain. Solar energy is leaeding among all the presently known methods of acquiring alternative energy sources. It is universal, inexhaustible, and least invasive for the natural environment. The scale of application thereof is also unlimited. In many regions, solar ener- 
gy plants are built on gigantic areas with a capacity of hundreds of MW. The largest solar plant is located in Southern California, where it occupies nearly 4 million $\mathrm{m}^{2}$ and boasts 350 megawatts of power. In Poland, the largest solar farms, as for the installed capacity, are located in: Czernikowo (3.77 MW), Ostrzeszów (2 MW), Kolno (1.84 MW), Przejazdowo/Gdańsk (1.64 MW), and Gubin (1.5 MW).

Despite its obvious advantages, solar energy is costly. In comparison with wind farms, it is more expensive and requires financial support. There is also a second issue - the lack of effective means of storing electricity. In the context of the entire energy infrastructure, the concept of energy accumulation basically does not exist. However, in the field of usable technology, progress is already visible, though still remains a technological challenge. So far, the largest battery in the world has been built jointly by the Chinese national energy company (SGCC) and the manufacturer of electric cars - BYD. This is a project able to store $36 \mathrm{MWh}$ of electricity. Such a reserve of energy may satisfy the energy demand of a town of 12,000 inhabitants for an hour. Taking the cost of construction of the entire project amounting to approximately USD $500 \mathrm{~m}$ into account, one may raise doubts as to the rationality of such undertakings. It makes sense when combining this type of technology with renewable energy sources. In this case, wind and solar power plants with a total capacity of $140 \mathrm{MW}$ exist. The use of giant "accumulators" may significantly mitigate the negative impact of daily volatility and the seasonality of electricity production in solar power plants (Rochała and Tincer 2018).

A somewhat different, albeit related branch of energy are portable household appliances and the automotive industry with bicycles and electric scooters. The matter is simple when it comes to home appliances. The A+ energy class is basically the standard. However, in the case of small portable equipment or vehicles, the matter is much more complicated. The development of technology and resulting energy consumption significantly exceed the increase in the energy storage capacity. In terms of the energy demand of new technologies, there seems to be no clear direction towards savings. One may form an impression that all producers are "awaiting" a sudden increase in the capacity of produced batteries.

The introduction of general use of lithium-ion technology, which quickly replaced the once dominant nickel-hydride technology was deemed an advancement. Current research includes, among others, lithium-ion batteries with the participation of air (oxygen) or sulfur. For instance, scientists from the Fraunhofer Institute in Pfinztal, Germany are investigating the use of so-called Redox - Flow - Battery as a drive for road vehicles. Scientific research may further improve this technology mainly through the use of materials which are able to accommodate a larger number of electrons, e.g. carbon electrodes are replaced with the silicon ones. Nanotechnology is also proving convenient, which is confirmed by engineers from the Massachusetts Institute of Technology. The use of carbon nanotubes may increase the capacity of batteries up to 10 times. Looking further ahead, one may expect the development of lithium-air batteries (Kotowski and Konopka 2013).

The issue found in the currently used batteries of electric cars is the fact that the higher their power, the heavier they are. For instance, for a distance of 250 kilometers and a single charge of the battery, it should weigh approximately 250 kilograms. A small car with an eight-hour battery 
charge is able to cover a distance of 130 kilometers. This type of battery has been adapted to 3,000 charging cycles which allow 300,000 kilometers of distance to be covered. In this situation, the Institute of Technology in Karlsruhe in Germany undertook research within the framework of the so-called nanotechnology. In practice, nanocells may store more than two times (in theory up to five times) more energy than the most effective batteries of the current generation.

Fuel cells are among most promising technologies on the energy market. Their operating principle is quite simple - the combustion of hydrogen and oxygen; these are entirely zero emission systems, fed with pure hydrogen or reformer. The membrane of the PEM cell is a polymeric material, e.g. Nafion. The advantage of fuel cells consists in the high efficiency of electricity production - up to $65 \%$ as well as a small amount of the released heat. They also display high pursuance of the cell in systems subjected to variable loads and a short start-up time. Such features result from the low temperature of the reaction occurring in the cell - 60 to 100 degrees Celsius and, most importantly, in theory, fuel cells do not discharge. They are smaller and lighter than other energy sources of comparable power, and the efficiency of generating electricity reaches up to $50 \%$. Fuel cells achieve efficiency of up to $85 \%$ in the process of cogeneration, the production of electricity and heat. Technical literature and the energy market recognize four basic cell types: phosphoric PAFC; carbonate MCFC; oxide SOFC; and polymer PEMFC (Małek and Wendeker 2010).

Implementing innovative communication solutions, which offer numerous opportunities for all types of energy-efficient solutions would seem a noteworthy idea on the energy market. This applies to projects for the introduction of electric and hybrid buses, and where conditions favorable to water gondolas exist. Bearing the civilization progress in the near future in mind, we may be heading for another revolution in the form of association of many innovative transport solutions using green energy. One should agree with Simla Kallas - Transport Commissioner at the European Commission who claims that by 2030 there should be a $50 \%$ reduction in "conventionally supplied" cars in cities, while by 2050 they should disappear from the market (Drożdż 2018).

Clusters are a slightly different form of new technologies introduced into the energy market. They constitute a platform for cooperation of: entrepreneurs, scientific-research units, and public authorities. The functioning of these entities is an important catalyst for the transfer of knowledge and technologies. The regional nature of clusters not only affects the competitiveness of the involved enterprises, but also exerts a positive impact on the development of the entire region. The Czorsztyn Reservoir operating in the district of Nowy Targ, including the municipal commune of Nowy Targ is an example of this the energy cluster. It is worth noting that at the close of 2015 there were 134 clusters in total, including 11 clusters in the Lower Silesia province, 4 in the Kuyavian-Pomeranian province, 11 in the Lublin province, 4 in the Lubusz province, 3 in the Lódź province, 10 in the Lesser Poland province, 14 in the Mazovia province, 1 in Opole province, 12 in the Subcarpathian province, 8 in the Podlaskie province, 5 in the Pomeranian province, 28 in the Silesia province, 4 in Świętokrzyskie province, 2 in the Warmian-Masurian province, 12 in the Greater Poland province, and 6 in the West Pomeranian province. On the other hand, there were approximately 33 of those involved in the energy 
market. For their development to take place, which has been emphasized by E. Mataczyńska, it is necessary to define transparent rules on which clusters will use electricity grids owned by electricity distribution companies. They should guarantee the security of the entire power system (Mataczyńska 2017).

\section{References}

BARTLETt, C. and GHOShal, P. 2011. Re-conceptualizing Bartlett and Ghoshal's Classification of National Subsidiary Roles in the Multinational Enterprise, $254 \mathrm{pp}$.

Colander et al. 2010 - Colander, D., Holt, R.P.F. and Rosser, J.B. 2010. European Economics at a Crossroads. $253 \mathrm{pp}$.

DAVENPORT, T.H. 2007. Knowledge management for knowledge workers (Zarządzanie pracownikami wie$d z y$ ), Kraków, 24 pp. (in Polish).

DROŻDŻ, W. ed. 2018. Electromobility in urban development (Elektromobilność w rozwoju miast). Warszawa: PWN, pp. 117-169 (in Polish).

DźWIGOŁ, H. 2010. Systemic approach in the process of enterprise restructuring (Podejście systemowe $w$ procesie restrukturyzacji przedsiębiorstwa). Gliwice, 64 pp. (in Polish).

e-Polska. Action plan for the development of the information society in Poland for the years 2001-2006 (e-Polska. Plan działań na rzecz rozwoju społeczeństwa informacyjnego w Polsce na lata 2001-2006). The Ministry of Economy, Warszawa 2001 (in Polish).

FlASZEWSKA, P. 2016. Organizational design in knowledge management (Projektowanie organizacyjne w zarządzaniu wiedza). Warszawa, pp. 18-27 (in Polish).

GASZ, M. 2013. Europe 2020 Strategy - assumptions and prospects for implementation (Strategia Europa 2020 - założenia i perspektywy realizacji). Wrocław, p. 86. CSO Statistical Yearbook 2016 (in Polish).

HEDLund, G. 1994. A model of Knowledge Management and the N-Form Corporation. Strategic Management Journal 15, pp. 73-90.

JAKIMOWACZ, A. 2016. The new economy. Complex systems and homo compositus (Nowa ekonomia. Systemy złożone i homo compositus). Warszawa, pp. 21-23 (in Polish).

JASIŃSKI, A.H. 2006. Innovation and technology transfer in the transformation process (Innowacje $i$ transfer techniki w procesie transformacji). Warszawa: Difin, 36 pp. (in Polish).

KANG et al. 2010 - KANG, J., RHEE, M. and KANG, K.H. 2010. Revisiting Knowledge transfer, Effects of Knowledge characteristics organizational effort for knowledge transfer. pp. 25-81.

KLEER, J. 2009. Knowledge-based economy and globalization: temporal and causal relationships (Gospodarka oparta na wiedzy a globalizacja: zwiazki czasowe i przyczynowe). p. 69 (in Polish).

KLINCEWICZ, K. 2008. The objectives of knowledge management (Cele zarzadzania wiedza) [In:] Jemielniak, D. and Koźmiński, A.K. ed. The knowledge management (Zarzadzanie wiedza), Warszawa, p. 81 (in Polish).

Kogut, B. and ZANDER, U. 1993. Knowledge of the Firm and the Evolutionary Theory of the Multinational Corporation. Journal of International Business Studies Vol. 24, Iss. 4, pp. 625-645.

KotOwSKI, W. and KonOPKA, E. 2014. Energy innovations in the road transport sector (Innowacje energetyczne w sektorze transportu drogowego). Energia Gigawat No. 4-5, 3 pp. (in Polish).

KUKLIŃSKI, A. 2001. The knowledge-based economy. Challenges for the 21 st century Poland (Gospodarka oparta na wiedzy. Wyzwania dla Polski XXI wieku). Warszawa, 15 pp. (in Polish).

KuKUŁA, A. 2013. The Knowledge-Based Economy as a strategy for the 21 st century economic development (Gospodarka Oparta na Wiedzy jako strategia rozwoju gospodarczego XXI wieku) [In:] New Stra- 
tegies for the New Age. Borders and possibilities of regional and global integration (Nowe strategie na nowy wiek. Granice i możliwości integracji regionalnych i globalnych). Scientific editors Chorośnicki, M., Węc, J., Czubik, A., Głogowski, A., Krzyżanowska-Skowronek, I., Nitszke, A., Szczepankiewicz -Rudzka, E., Tarnawski, M., Jagiellonian University Publishing House, Kraków, 563 pp. (in Polish).

KWIECIEŃ, K. and MAJEWSKI, M. 2001. The secrets of using knowledge (Tajniki wykorzystania wiedzy) [In:] Knowledge management in an enterprise (Zarzadzanie wiedza w przedsiębiorstwie). Warszawa: Polska Fundacja Promocji Kadr, 71 pp. (in Polish).

MĄCZYŃSKA, E. 2014. The Main Determinants of Socio-Economic Development [In:] Economics questions, issues and problems, János Tibor Karlovitz ed. p. 23.

MAteK, A. and WNEDEKER, M. 2010. The theory and practice of PEM fuel cells (Ogniwa paliwowe typu PEM teoria i praktyka). Lublin, p. 12 (in Polish).

MATACZYŃSKA, E. 2017. Energy clusters from the perspective of implementing a new market model based on the functioning of microgrids (Klastry energii z perspektywy wdrożenia nowego modelu rynku opartego na funkcjonowaniu mikrosieci). KOMENTARZ IPE No. 1, 9 pp. (in Polish).

MiśKIEWICZ, R. 2017. The knowledge transfer in mergers and acquisitions of enterprises in the steel industry (Transfer wiedzy w procesach fuzji i przejęć przedsiębiorstw $w$ branży hutniczej). Warszawa, p. 25-26 (in Polish).

NONAKE, I. and TAKEUCHI, H. 2000. Creating knowledge in the organization (Kreowanie wiedzy w organizacji). Poltext, Warszawa, p. 78 (in Polish).

NowAK, P. 2013. Poland in the rankings of knowledge-based economies (Polska w rankingach gospodarek opartych na wiedzy). Prace Komisji Geografii Przemysłu Polskiego Towarzystwa Geograficznego No. 20, p. 39 (in Polish).

PAPIŃSKA-KACPEREK, J. 2006. The information society (Spoleczeństwo informacyjne). Warszawa, p. 17 (in Polish).

PODCZARSKI, P. 2016. Economic efficiency of restructuring processes of industrial enterprises. The example of ironworks in Poland (Efektywność ekonomiczna procesów restrukturyzacji przedsiębiorstw przemystowych. Na przyktadzie hut żelaza w Polsce). Warszawa, p. 33 (in Polish).

POLAK, A. 2012. The knowledge map based teaching enterprises to an organization (Nauczanie organizacji przedsiębiorstw za pomoca mapy wiedzy). Warszawa, p. 10 (in Polish).

PORTER, M.E. 1992. The competition strategy. Methods for analyzing sectors and competitors (Strategia konkurencji. Metody analizy sektorów i konkurentów). Warszawa, p. 36 (in Polish).

Ring, A. and ÖfVerström, H. 2000. Contextualised View of Knowledge Transfer in Mergers and Acquisitions. Göteborg, p. 54.

RochatA, P. and TINCER, M. 2018. The new technologies, transfer of knowledge and technologies, energy industry - directions of changes in Lower Silesia, Poland, trends in the world. ARI (Nowe technologie, transfer wiedzy i technologii, energetyka - kierunki zmian na Dolnym Śląsku, Polsce, trendy na świecie. ARI). Wrocław, pp. 1-11 (in Polish).

RYBIŃSKI, K. 2015. Kings of innovation at the service of finance (Królowie innowacji na ustugach finansowych). Helion, Gliwice, p. 62 (in Polish).

SANTAREK et al. 2008 - SANTAREK, K., BAgiŃSKI, J., BuCZACKI, A., SoBCZAK, D. and SZERENOS, A. 2008. Technology transfer from university to business. Creating technology transfer mechanisms (Transfer technologii z uczelni do biznesu. Tworzenie mechanizmów transferu technologii). Warszawa: PARP, p. 67 (in Polish).

SKRZYPEK, E. 2010. The knowledge management and its role in modern management (Zarzadzanie wiedza i jego rola we wspótczesnym zarządzaniu) [In:] The knowledge and innovations management in contemporary organisations (Zarządzanie wiedza i innowacjami we wspótczesnych organizacjach) Lachiewicz, P. and Zakrzewska-Bielawska, A. ed., Łódź, p. 273 (in Polish). 
SKRZYPEK, E. 2011. Knowledge based economy and its determinants (Gospodarka oparta na wiedzy i jej wyznaczniki). Lublin, p. 90 (in Polish).

SKYRME, D.J. 1999. Knowledge Commerce: Succeeding in a Global Knowledge Marketplace, Knowledge Economy Conference Beijing, 18 pp.

The Lisbon Strategy [Online] http://www.cie.gov.pl/HLP/filep.nsf/0/E47981D8B0655EA1C125711D003CDD1D/\$file/strategia_lisbonska.pdf [Accessed: 2018-04-20] (in Polish).

StroJnY, M. 2000. Knowledge management - general outline of the notion (Zarzqdzanie wiedza ogólny zarys koncepcji). No. 2, Warszawa (in Polish).

SZATKOWSKI, K. 2016. Management of innovation and technology transfer (Zarzadzanie innowacjami i transferem technologii). Warszawa, p. 260 (in Polish).

TOFFLER, A. 2003. Change of power. Knowledge, wealth, and violence in the 21 st century (Zmiana wladzy. Wiedza, bogactwo i przemoc progu XXI wieku). Poznań, p. 72 (in Polish).

Act of 20 February 2015 on renewable energy sources, Amendment of 01.07.2016 Art.2(15a), Art. 38a. (36) [Energy Cluster] (Ustawa z dnia 20 lutego 2015 r. o odnawialnych źródtach energii, Nowelizacja z dnia 01.07.2016 Art.2. ust.15a, Art. 38a. (36) [Klaster energii]) (in Polish).

WOŹNIAK, M.G. 2008. The model of social and economic cohesion of the European Union: conclusions for Poland (Model spójności spoleczno-ekonomicznej Unii Europejskiej: wnioski dla Polski). Nierówności Społeczne a Wzrost Gospodarczy Iss. 12, pp. 23-29 (in Polish).

\author{
Radosław MiŚKIEWICZ
}

\title{
Znaczenie transferu wiedzy na rynku energii
}

\section{Streszczenie}

Prawo energetyczne z 10 kwietnia 1997 roku zapoczątkowało zmiany na rynku energii w Polsce. Na jego podstawie podjęto działania ukierunkowane na modernizację i rozwój sektora elektroenergetycznego. Wprowadzono zmiany organizacyjne i prawne powodujące rozwój generacji rozproszonej, zwiększając tym samym poziom konkurencji rynkowej. Dbałość o wysoką jakość obsługi klientów w tym ochrona wrażliwych odbiorców, ochrona środowiska, rosnący udział energii odnawialnej oraz wymogi w zakresie redukcji emisji stały się faktem. Wydaje się więc, że dla polskiego sektora energetyki konieczne staną się: jego permanentna modernizacja, rozbudowa infrastruktury wytwórczej i przemysłowej oraz rozwój nowoczesnych technologii konwencjonalnych wdrażając innowacje w zakresie funkcjonowania przedsiębiorstw energetycznych. Autor w niniejszym artykule stawia tezę, że nieodzowne jest, by na bazie gospodarki opartej na wiedzy dokonywać szeroko rozumianego transferu wiedzy i technologii do sektora energetyki. Odnosi się to także do klastrów energii, które współcześnie stanowią platformę współpracy: przedsiębiorców, jednostek naukowo-badawczych oraz władz publicznych. Funkcjonowanie tych podmiotów jest ważnym katalizatorem transferu wiedzy i technologii. Ich regionalny charakter podnosi konkurencyjność zaangażowanych przedsiębiorstw, jest naturalnym sposobem transferu wiedzy na rynek energii.

SŁOWA KLUCZOWE: liberalizacja rynku, transfer wiedzy na rynek energii, elektromobilność, klaster energii 